\title{
Nutrient intake and digestibility of the lipid residue of biodiesel from palm oil in sheep ${ }^{1}$
}

\section{Laura Cristina Barra Raiol ${ }^{2}$, Fernando Kuss ${ }^{3}$, André Guimarães Maciel e Silva ${ }^{5}$, Bruno Cabral Soares ${ }^{2}$, Karla Débora Santana de Souza ${ }^{2}$, Juliana Cristina Nogueira Colodo ${ }^{4}$, José de Brito Lourenço Júnior ${ }^{6}$, Sandra Cristina de Ávila ${ }^{5}$}

\author{
${ }^{1}$ Project funded by Fapespa, Brazil. \\ 2 UFPA - Belém, PA, Brazil. \\ ${ }^{3}$ UTFPR - Dois Vizinhos, PR, Brazil. \\ ${ }^{4}$ UFMG - Belo Horizonte, MG, Brazil. \\ ${ }^{5}$ FMV - UFPA - campus de Castanhal, PA, Brazil. \\ ${ }^{6}$ UEPA - Belém, PA, Brazil.
}

\begin{abstract}
The objective of this study was to evaluate the effect of inclusion of lipid residue of biodiesel originated in the processing of palm oil (Elaeis guineensis) in the diet on the digestibility of feedlot lambs. Twenty-five crossbred male castrated lambs, weighing $20 \pm 1.61 \mathrm{~kg}$, were distributed in randomized blocks with five treatments and five replications. The experimental period lasted 22 days; 15 for diet adaptation, 2 for the adaptation to the indicator LIPE (lignin from Eucalyptus grandis isolated, purified and enriched, UFMG, Minas Gerais) and 5 for fecal sampling. Diets were formulated with $64 \%$ concentrate based on corn and soybean meal, 31\% Massai grass (Panicum maximum cv. Massai) hay and 5\% lipid supplementation from increasing levels of substitution of $0,25,50,75$ and $100 \%$ of palm oil for biodiesel oil from palm residue. The lambs were offered two meals a day, at $7 \mathrm{~h} 00$ and $16 \mathrm{~h} 00$. There was linear effect of inclusion of the residue from palm oil biodiesel on dry matter intake. There was no change in digestibility of nutrients except for ether extract. The use of biodiesel from palm oil residue up to $100 \%$ replacement for the lipid supplementation of sheep positively influences the consumption without altering the digestibility of nutrients.
\end{abstract}

Key Words: lipid supplementation, nutrition, ruminating

\section{Introduction}

Biodiesel is currently in the center of attention and interests of the energy sector due to the growing worldwide concern about environmental issues associated with the search for renewable energy sources. The production of biodiesel from palm oil (Elaeis guineensis) provides an opportunity for the integration between the industry and family farming, as well as for the fight against poverty, which reinforces the global interest in acquiring a new pattern of energy: sustainable, environmentally friendly and economically feasible (Ferreira \& Cristo, 2006).

The production of biodiesel is performed by reactions of transesterification, in which the glycerin is separated from the vegetable oil, which divides the process in light phase and heavy phase. The glycerin distillation happens in the heavy phase, generating the distilled glycerin and the glyceric residue, both used in animal feeding (Lage et al., 2010). The purification of the esters occurs in the light phase, which generates biodiesel. When it is distilled, it generates a lipid residue which consists of a pasty dark material rich in fatty acids. Because of these characteristics, it is believed that this product can be used as a lipid supplementation in ruminant diets.

The use of unsaturated lipids in diets for ruminants provides both desirable effects, such as inhibiting the production of methane and ammonia in the rumen, and undesirable effects, such as reduction in digestibility of dry matter (DM), organic matter (OM) and cellulose. The lipids are mainly used to increase the energy density of diets due to the higher energy value presented when compared with carbohydrate (Harfoot \& Hazlewood, 1997).

The fatty acid content found in oilseeds ranges from $18 \%$ to $40 \%$, and most of the lipids found in plants are of the unsaturated type. In most of the cereals and oilseeds there is predominance of linoleic acid (18:2 n-6) and in the case of biodiesel residue from palm oil, there is a predominance of palmitic, oleic and linoleic acids (Palmquist \& Mattos, 2006).

Thus, the objective of this study was to evaluate the performance of sheep fed diets with different levels of substitution of palm oil for its lipid residue originated during the processing of biodiesel. 


\section{Material and Methods}

The experiment was conducted from October to November 2009, at Instituto Federal de Educação, Ciência e Tecnologia do Pará - IFPA, Campus Castanhal, with the average annual temperature of $30^{\circ} \mathrm{C}$ and average humidity around 96\% (UFPA, 2011). Twenty-five crossbred male castrated lambs, weighing $20 \pm 1.61 \mathrm{~kg}$ were fed diets supplemented with $5 \%$ lipid residue of biodiesel from palm oil, replacing palm oil at the following levels: $0,25,50,75$ and $100 \%$.

The animals were previously wormed, then housed in covered masonry shed, in individual stalls lined with sawdust bedding, with access to feeders, with room to forage and concentrate, and individual water drinker, in which water was supplied freely. The experimental period lasted 22 days; 15 days for diet adaptation, 2 days for the adaptation to the external indicator LIPE (lignin from Eucalyptus grandis isolated, purified and enriched, UFMG, Minas Gerais), and 5 days for fecal sampling.

The experimental diets (Tables 1 and 2) consisted of $310 \mathrm{~g}$ of chopped Massai hay $/ \mathrm{kg}, 640 \mathrm{~g}$ of concentrate $/ \mathrm{kg}$ of diet, based on corn and soybean meal, and $50 \mathrm{~g}$ of lipid/ $\mathrm{kg}$ of diet. The supply of the diets to the sheep was divided into two meals a day, at $7 \mathrm{~h} 00$ and $16 \mathrm{~h} 00$, to allow leftover sof $10 \%$ from the diet offered.
The lipid residue of biodiesel from palm oil and the palm oil were incorporated manually and homogenized to the concentrate according to the substitution levels in the following treatments: $100 \%$ palm oil; $75 \%$ palm oil and $25 \%$ residue; $50 \%$ palm oil and $50 \%$ residue; $25 \%$ palm oil and $75 \%$ residue; and $100 \%$ biodiesel residue.

To determine the composition of fatty acids, palm oil and biodiesel lipid residue were esterified according to the method of Hartman \& Lago (1973), and the fatty acid composition was determined by gas chromatography. The fatty acid content in the experimental diets was calculated on the amount of each fatty acid present in the palm oil and lipid residue and the proportions of fat sources in the different treatments (Table 3).

To estimate the fecal excretion, external indicator LIPE (lignin from Eucalyptus grandis isolated, purified and enriched, UFMG, Minas Gerais) was administered at a dosage of $0.1 \mathrm{~g}$ daily in gelatin capsules in the morning to each animal, during seven days with two days for the stabilization of excretion and five days for fecal sampling.

The fecal samples were collected daily in the morning (8h00) for five days straight from the rectum. Also during this period, the feed supplied and leftovers were sampled daily. The feeds supplied were sampled before the morning meal and the leftovers were collected and weighed.

Table 1 - Chemical composition of forage and experimental concentrates in $\mathrm{g} / \mathrm{kg}$ dry matter

\begin{tabular}{|c|c|c|c|c|c|c|}
\hline \multirow{2}{*}{ Item } & \multirow{2}{*}{ Hay } & \multicolumn{5}{|c|}{ Levels of substitution of palm oil for the biodiesel residue } \\
\hline & & $0 \%$ & $25 \%$ & $50 \%$ & $75 \%$ & $100 \%$ \\
\hline Dry matter & 874.7 & 840.7 & 846.6 & 844.4 & 840.6 & 847.9 \\
\hline Mineral matter & 52.0 & 21.3 & 24.8 & 29.0 & 26.6 & 29.8 \\
\hline Crude protein & 50.4 & 152.4 & 148.9 & 149.6 & 150.4 & 158.4 \\
\hline Ether extract & 17.9 & 146.2 & 161.6 & 170.4 & 165.6 & 141.8 \\
\hline Neutral detergent fiber & 602.8 & 169.0 & 190.4 & 158.8 & 189.7 & 156.2 \\
\hline Non-fibrous carbohydrates & 276.9 & 518.3 & 477.6 & 495.3 & 477.9 & 519.9 \\
\hline
\end{tabular}

Table 2 - Chemical composition of experimental diets in $\mathrm{g} / \mathrm{kg}$ dry matter

\begin{tabular}{|c|c|c|c|c|c|}
\hline \multirow{2}{*}{ Item } & \multicolumn{5}{|c|}{ Levels of substitution of palm oil for the biodiesel residue } \\
\hline & $0 \%$ & $25 \%$ & $50 \%$ & $75 \%$ & $100 \%$ \\
\hline Dry matter & 851.2 & 855.3 & 853.8 & 851.2 & 856.2 \\
\hline Organic matter & 969.2 & 966.8 & 963.9 & 965.5 & 963.3 \\
\hline Mineral matter & 25.8 & 31.0 & 34.0 & 27.4 & 32.5 \\
\hline Crude protein & 120.8 & 118.4 & 118.8 & 119.4 & 124.9 \\
\hline Ether extract & 106.4 & 117.1 & 123.1 & 119.8 & 103.4 \\
\hline Neutral detergent fiber & 303.5 & 318.2 & 296.4 & 317.8 & 294.6 \\
\hline Non-fibrous carbohydrates & 443.4 & 415.3 & 427.5 & 415.5 & 444.5 \\
\hline
\end{tabular}


The samples were packed in plastic bags, identified and stored at $-20{ }^{\circ} \mathrm{C}$. At the end of the experimental period, the samples were thawed at room temperature and homogenized for the preparation of composite samples. These samples were prepared from the manual mixture of $10 \%$ from each daily sample either from the feed supplied or leftovers per animal. Sequentially, the samples were weighed and predried in a forced-ventilation oven at $65{ }^{\circ} \mathrm{C}$ for 72 hours, ground in Wiley-type mill TE 650 in $1 \mathrm{~mm}$ mesh sieve and stored at room temperature.

The determination of dry matter (DM), organic matter $(\mathrm{OM})$, crude protein $(\mathrm{CP})$, mineral matter $(\mathrm{MM})$ and ethereal extract (EE) in samples of feed supplied, leftovers and feces were analyzed according to the techniques described by Silva \& Queiroz (2002). For the quantification of fibrous fractions - neutral detergent fiber (NDF), acid detergent fiber (ADF), hemicellulose, cellulose and lignin, the sequential method described by Van Soest et al. (1991), with Ankon Fiber Analyzer equipment was used, with polyester bags (non-woven textile, TNT), weight $100 \mathrm{~mm}$ (Araújo et al., 2009). Prior to determining the fibrous fractions, the samples were defatted by the Soxlet method, and the yields of ethereal extract samples were obtained by the same method (Komarek, 1993).

The non-fibrous carbohydrates (NFC) of feed, leftovers and feces were calculated according to Sniffen et al. (1992): $\mathrm{NFC}=100-(\mathrm{NDF}+\mathrm{EE}+\mathrm{CP}+\mathrm{MM})$, in which $\mathrm{EE}=$ ether extract; $\mathrm{CP}=$ crude protein; and $\mathrm{MM}=$ mineral matter. The total digestible nutrients (TDN) were calculated by using the following equation: TDN $=$ digestible $\mathrm{CP}+$ digestible $\mathrm{EE} *(2.25)+$ digestible NDF + digestible NFC (NRC, 2001), in which NFC stand for non-fibrous carbohydrates.
The daily nutrient intake was calculated by the difference between the quantities offered and their leftovers.

The experimental design was in randomized blocks, according to the initial weight of the animals, with five treatments and five repetitions. The results were analyzed by applying analysis of variance and linear regression, using $5 \%$ for the critical level of probability for type I error, by PROC REG of SAS (Statistical Analysis System, version 6).

\section{Results and Discussion}

The rising levels of palm oil biodiesel residue influenced $(\mathrm{P}<0.05)$ the dry matter intake $(\mathrm{DMI})$, organic matter intake (OMI), $\mathrm{CP}$ and EE expressed in grams per day and $\mathrm{g} / \mathrm{kg}$ body weight (BW). The intakes of NDF and NFC were not affected $(\mathrm{P}>0.05)$ by fat supplements, when expressed in $\mathrm{g} / \mathrm{day}$ and $\mathrm{g} / \mathrm{kg} \mathrm{BW}$ (Table 4).

The intake of dry matter (DMI), crude protein and organic matter, expressed in g/day, had a positive linear effect, which indicates increasing consumption in those with elevated levels of residue in the diet. The ether extract intake (EEI) presented quadratic effect, indicating a decrease in consumption of these nutrients. The average DMI in $\mathrm{g} / \mathrm{kg}$ body weight (BW) was lower than those cited by the NRC (2007), which shows values close to $50.0 \mathrm{~g} / \mathrm{kg}$ BW for sheep, except for the treatments of $50 \%$ and $100 \%$ of replacement, which were respectively 4.07 and $4.06 \mathrm{~g} / \mathrm{kg}$ BW of DMI.

The fatty acid composition may have increased the consumption, as the increase in residue levels in the diet, making it richer in saturated fatty acids, without implying

Table 3 - Fatty acids in $\mathrm{g} / \mathrm{kg}$ of experimental diets

\begin{tabular}{|c|c|c|c|c|c|c|}
\hline \multirow{2}{*}{ Fatty acid } & \multirow{2}{*}{$\begin{array}{l}\text { Chemical } \\
\text { formula }\end{array}$} & \multicolumn{5}{|c|}{ Levels of substitution of the palm oil for the biodiesel residue } \\
\hline & & $0 \%$ & $25 \%$ & $50 \%$ & $75 \%$ & $100 \%$ \\
\hline Caprylic & $\mathrm{C} 8: 0$ & 0 & 0.05 & 0.10 & 0.15 & 0.21 \\
\hline Capric & C10:0 & 0 & 0.05 & 0.10 & 0.15 & 0.20 \\
\hline Lauric & $\mathrm{C} 12: 0$ & 0.24 & 0.71 & 1.18 & 1.65 & 2.12 \\
\hline Myristic & C14:0 & 0.78 & 0.86 & 0.94 & 1.02 & 1.11 \\
\hline Palmitic & C16:0 & 38.37 & 38.37 & 38.37 & 38.37 & 38.38 \\
\hline Palmitoleic & C16:1 & 0.14 & 0.14 & 0.14 & 0.14 & 0.15 \\
\hline Margaric & C17:0 & 0.10 & 0.11 & 0.12 & 0.13 & 0.15 \\
\hline Stearic & C18:0 & 5.03 & 4.94 & 4.85 & 4.76 & 4.67 \\
\hline Oleic & C18:1 & 43.04 & 41.69 & 40.34 & 38.99 & 37.64 \\
\hline Linoleic & $\mathrm{C} 18: 2$ & 11.36 & 11.78 & 12.21 & 12.63 & 13.06 \\
\hline Linolenic & C18:3 & 0.31 & 0.42 & 0.53 & 0.64 & 0.75 \\
\hline Arachidic & C20:0 & 0.34 & 0.35 & 0.37 & 0.39 & 0.41 \\
\hline Total & & 99.71 & 99.49 & 99.28 & 99.06 & 98.85 \\
\hline Saturated & & 44.86 & 45.45 & 46.05 & 46.65 & 47.25 \\
\hline Unsaturated & & 54.85 & 54.03 & 53.22 & 52.41 & 51.60 \\
\hline Saturated:unsaturated ratio & & 0.81 & 0.84 & 0.86 & 0.89 & 0.91 \\
\hline
\end{tabular}


limitation of consumption. According to Palmquist \& Mattos (2006), saturated fatty acids have low microbial inhibitory activity, yet they have low digestibility when compared with unsaturated fatty acids.

Studies such as that of Allen (2000) indicate that the reduction in DM intake, commonly observed in studies with additional sources of lipids in the diet, may be related to plasma concentrations of oleic and linoleic fatty acids, resulting from the metabolism of these sources, which may also explain the quadratic effect of EEI. These fatty acids comprise, at considerable levels, the fatty acid composition of palm oil and residue of biodiesel. Still according to Allen (2000), diets high in lipid concentration increase the concentration of cholecystokinin in plasma and there is a chance that this hormone suppresses feed intake by the inhibition of gastric emptying. Receptors of this hormone send information to the brain, causing a reduction in appetite and thus dry matter intake by the animals. Therefore, in a study with sheep fed diets rich in unsaturated fatty acids, Jenkins \& Thies (1997) found a reduction in DM intake as a consequence of increased plasma concentration of linoleic acid.

However, in cows fed $3.5 \%$ protected oil sources, Jenkins et al. (1996) observed no reduction in DM intake, even when the animals had high plasma concentrations of linoleic acid. Furthermore, Kelly et al. (1998) evaluated sources of vegetable oils rich in polyunsaturated fatty acids (oleic, linoleic and linolenic) in the diet of dairy cows and found that DM intake was not altered by lipid source added to the diet.

The absence of change in NDF intake may be related to diets, which had very close fiber values, lipid supplementation at 5\% and high saturated:unsaturated fatty acid ratio. According to Palmquist \& Mattos (2006), lipid supplementation higher than $5 \%$ of dry matter can compromise the intake, either by regulatory mechanisms that control feed intake or by limited capacity of ruminants to oxidize fatty acids.

The increasing levels of palm oil biodiesel residue did not significantly alter the digestibility coefficients of DM, OM and CP. However, EE digestibility showed linear effect. The digestibility coefficients of NDF and NFC followed the trend of their consumption not being affected $(\mathrm{P}>0.05)$ by dietary fat supplements (Table 5).

Intake is generally directly related to the digestibility; however, systems such as the nutritional National Research Council (NRC, 2007) state that digestibility is inversely related to feed intake. Van Soest \& Fox (1992)

Table 4 - Means and regression equations for total daily intake of sheep fed palm oil biodiesel residue in place of oil palm

\begin{tabular}{|c|c|c|c|c|c|c|c|c|c|}
\hline \multirow{2}{*}{ Item } & \multicolumn{5}{|c|}{ Replacement levels of palm oil for biodiesel residue } & \multirow{2}{*}{$\mathrm{CV}(\%)$} & \multicolumn{3}{|c|}{$P$ value } \\
\hline & $0 \%$ & $25 \%$ & $50 \%$ & $75 \%$ & $100 \%$ & & Linear & Quadratic & Lack of fit \\
\hline Dry matter intake $(g)^{1}$ & 665.39 & 765.41 & 943.06 & 761.61 & 946.52 & 17.80 & 0.014 & 0.449 & 0.169 \\
\hline Dry matter intake $(\mathrm{g} / \mathrm{kg} \mathrm{BW})^{2}$ & 2.81 & 3.33 & 4.07 & 3.32 & 4.06 & 17.42 & 0.010 & 0.319 & 0.144 \\
\hline Organic matter intake $(\mathrm{g})^{3}$ & 645.89 & 751.50 & 932.99 & 731.36 & 854.24 & 17.05 & 0.054 & 0.121 & 0.178 \\
\hline Crude protein intake $(\mathrm{g})^{4}$ & 88.38 & 101.14 & 123.24 & 100.86 & 124.38 & 16.66 & 0.001 & 0.456 & 0.157 \\
\hline Ether extract intake $(\mathrm{g})^{5}$ & 78.67 & 102.83 & 127.44 & 109.69 & 111.35 & 19.18 & 0.024 & 0.070 & 0.455 \\
\hline Neutral detergent fiber intake $(\mathrm{g})$ & 167.17 & 206.00 & 244.66 & 192.49 & 221.66 & 20.09 & 0.131 & 0.115 & 0.154 \\
\hline Neutral detergent fiber intake (g/kg BW) & 0.71 & 0.88 & 1.04 & 0.83 & 0.96 & 19.62 & 0.095 & 0.111 & 0.141 \\
\hline Non-fibrous carbohydrates intake (kg/day) & 172.65 & 131.55 & 202.97 & 107.74 & 143.09 & 28.05 & 0.196 & 0.849 & 0.776 \\
\hline Total digestible nutrients intake $(\mathrm{kg} / \mathrm{day})^{6}$ & 866.49 & 973.40 & 1241.73 & 896.15 & 1004.23 & 18.96 & 0.488 & 0.051 & 0.250 \\
\hline
\end{tabular}

CV - coefficient of variation; IW - initial weight; L - level; BW - body weight.

${ }^{1} 0.1009+0.0259 \mathrm{IW}+0.0022 \mathrm{~L}\left(\mathrm{R}^{2}=0.53\right)$.

$23.8553-0.0359 \mathrm{IW}+0.0099 \mathrm{~L}\left(\mathrm{R}^{2}=0.27\right)$

${ }^{3} 0.0858+0.0266 \mathrm{IW}+0.0016 \mathrm{~L}\left(\mathrm{R}^{2}=0.52\right)$.

${ }^{4} 0.0003+0.0040 \mathrm{IW}+0.0003 \mathrm{~L}\left(\mathrm{R}^{2}=0.60\right)$.

${ }^{5} 0.0119+0.0029 \mathrm{IW}+0.0013 \mathrm{~L}-0.000009 \mathrm{~L}^{2}\left(\mathrm{R}^{2}=0.62\right)$.

${ }^{6} 0.1178+0.0322 \mathrm{IW}+0.0078 \mathrm{~L}-0.00007 \mathrm{~L}^{2}\left(\mathrm{R}^{2}=0.50\right)$.

Table 5 - Means and regression equations of digestibility coefficients

\begin{tabular}{|c|c|c|c|c|c|c|c|c|c|}
\hline \multirow{2}{*}{ Item } & \multicolumn{5}{|c|}{ Replacement levels of palm oil for biodiesel residue } & \multirow{2}{*}{$\mathrm{CV}(\%)$} & \multicolumn{3}{|c|}{ P value } \\
\hline & $0 \%$ & $25 \%$ & $50 \%$ & $75 \%$ & $100 \%$ & & Linear & Quadratic & Lack of fit \\
\hline Dry matter digestibility & 746.7 & 704.6 & 759.9 & 701.6 & 739.4 & 6.19 & 0.805 & 0.558 & 0.984 \\
\hline Organic matter digestibility & 754.3 & 720.7 & 771.8 & 706.8 & 734.2 & 6.18 & 0.428 & 0.944 & 0.909 \\
\hline Crude protein digestibility & 703.4 & 628.9 & 725.4 & 606.1 & 679.9 & 10.49 & 0.514 & 0.508 & 0.832 \\
\hline Ether extract digestibility ${ }^{1}$ & 817.8 & 744.1 & 789.9 & 663.8 & 659.5 & 7.36 & $<0.0001$ & 0.754 & 0.975 \\
\hline Neutral detergent fiber digestibility & 475.1 & 452.8 & 522.7 & 415.3 & 478.9 & 18.20 & 0.815 & 0.969 & 0.536 \\
\hline Non-fibrous carbohydrates digestiblity ${ }^{2}$ & 807.2 & 785.9 & 822.6 & 885.2 & 850.3 & 7.76 & 0.059 & 0.989 & 0.096 \\
\hline
\end{tabular}

CV - coefficient of variation.

${ }^{1} 77.2961+0.1758 \mathrm{PINI}-0.1585 \mathrm{NIV}\left(\mathrm{R}^{2}=0.54\right)$

$249.3044+1.2884 \mathrm{PINI}+0.0743 \mathrm{NIV}\left(\mathrm{R}^{2}=0.52\right)$ 
and Faichney (1993) report that the increase in feed intake normally increases the rate of passage of the digesta through the gastrointestinal tract and reduces its digestibility. Otherwise, the higher the consumption, the lower the retention time and the faster the rate of passage of feed through the digestive tract and, consequently, the particles will be less time in contact with the bacteria, which promotes a less potential digestibility of feed.

The results obtained in this study were similar to those found by Villaça et al. (1999), who evaluated the effect of adding soybean oil, $2.9 \%$ of the total diet, in an in vitro digestibility assay, and did not notice any change in NDF digestibility when fat was introduced in the oil form, but there was a reduction in protein digestibility with the use of whole seed oil.

A positive feature of the diets occurs in the increase in the saturated:unsaturated fatty acid ratio, as increasing levels of substitution of palm oil for biodiesel residue. With the increase of levels of replacement, the diet becomes richer in saturated fatty acids, which cause fewer deleterious effects on fiber digestibility when compared with unsaturated fatty acids. Unsaturated fatty acids have an antimicrobial effect on the rumen fermentation, being toxic to gram-positive bacteria, whose mechanism may involve a change in cell membrane permeability, which reduces the ability of the cell to regulate the intracellular $\mathrm{pH}$ and nutrient uptake; consequently, it reduces the rumen fermentation of fiber (Palmquist \& Mattos, 2006).

\section{Conclusions}

The use of palm oil biodiesel residue, at up to $100 \%$ in the lipid supplement for sheep positively influences intake with no effect on apparent digestibility of dry matter and fiber.

\section{Acknowledgements}

The authors are grateful to all study participants for their contributions and to IFPA - Campus Castanhal, PA, to Faculdade de Medicina Veterinária/UFPA - Campus Castanhal, PA, to Embrapa Amazônia Oriental, to Laboratory of Animal Nutrition in UFRA, and also to PROCAD - NF $N^{\circ}$ 08/2008 - CAPES, with the Project entitled "Research and Graduation in Animal Nutrition in Amazon: articulation between Animal Science/UFPA/UFRA/EMBRAPA and Animal Science UFMG".

\section{References}

ALLEN, M.S. Effects of diet on short-term regulation of feed intake by lactating dairy cattle. Journal of Dairy Science, v.83, p.1598-1624, 2000.

ARAÚJO, M.J.; MEDEIROS, A.N.; CARVALHO, F.F.R. et al. Consumo e digestibilidade dos nutrientes em cabras Moxotó recebendo dietas com diferentes níveis de feno de maniçoba. Revista Brasileira de Zootecnia, v.38, n.6, p.1088-1095, 2009.

FAICHNEY, G.J. Digesta flow. In: FORBES, J.M.; FRANCE, J. (Eds.) Quantitative aspects of ruminants digestion and metabolism. Wallingford: CAB International, 1993. p.53-85.

FERREIRA, J.R.; CRISTO, C.M.P.N. O futuro da indústria: biodiesel - coletânea de artigos. Brasília: MDIC-STI/IEL, 2006. 145p.

HARFOOT, C.G.; HAZLEWOOD, G.P. Lipid metabolism in the rumen. In: HOBSON, P.N.; STEWART, C.S. (Eds.) The ruminal microbial ecosystem. London: Chapman \& Hall, 1997. p.382-426.

HARTMAN, L.; LAGO, R.C. Rapad preparation of fatty acid methyl esters from lipids. Laboratory Practice, v.22, p.475-476, 1973.

JENKINS, T.C.; THIES, E. Plasma fatty acids in sheep fed hydroxyethylsoyamide: a fatty acylamide that resist biohydrogenation. Lipids, v.32, p.173-178, 1997.

JENKINS, T.C.; BATEMAN, H.G.; BLOCK, S.M. Butylsoyamide increases unsaturation of fatty acids in plasma and milk of lactating dairy cows. Journal of Dairy Science, v.79, p.585-590, 1996.

KELLY, M.L; BERRY, J.R.; DWYER, D.A. et al. Dietary fatty acid sources affect conjugated linoleic acid concentrations in milk from lactating dairy cows. Journal of Nutrition, v.128, p.881-885, 1998.

KOMAREK, A.R. A fiber bag procedure for improved efficiency of fiber analyses. Journal of Dairy Science, v.76, p.250, 1993.

LAGE, F.J.; PAULINO, P.V.R.; PEREIRA, L.G.R. et al. Glicerina bruta na dieta de cordeiros terminados em confinamento. Pesquisa Agropecuária Brasileira, v.45, n.9, p.1012-1020, 2010.

NATIONAL RESEARCH COUNCIL - NRC. Nutrient requirements of dairy cattle. 7.ed. Washington, D.C.: National Academy Press, 2001.381p.

NATIONAL RESEARCH COUNCIL - NRC. Nutrient requirement of small ruminants: Sheep, goats, cervids and new camelids. Washington: National Academy Press, 2007. 384p.

PALMQUIST, D.L.; MATTOS, W.R.S. Metabolismo de lipídeos. In: BERCHIELLI, T. T.; PIRES, A.V.; OLIVEIRA, S.G. (Eds.) Nutrição de ruminantes. Jaboticabal: Funep, 2006. 583p.

SILVA, D.J.; QUEIROZ, A.C. Análise de alimentos: métodos químicos e biológicos. 3.ed. Viçosa, MG: UFV, 2002. 235p.

SNIFFEN, C.J.; O'CONNOR, J.D.; VAN SOEST, P.J. et al. A net carbohydrate and protein system for evaluating cattle diets. Carbohydrate and protein availability. Journal of Animal Science, v.70, p.3562-3577, 1992.

UNIVERSIDADE FEDERAL DO PARÁ - UFPA. Localização de Castanhal. Available at: <http://www.ufpa.br/cebran/pages/ localizacao.htm $>$. Accessed on: Jan. 20, 2011.

VAN SOEST, P.J.; ROBERTSON, J.B.; LEWIS, B.A. Methods for dietary fiber, neutral detergent fiber and nonstarch polysaccharides in relation to animal nutrition. Journal of Dairy Science, v.74, p.3583-3597, 1991.

VAN SOEST, P.J.; FOX, D.G. Discounts for net energy and protein, fifth revision. In: CORNELL NUTRITIONAL CONFERENCE, 1992, New York. Proceedings... Ithaca: Cornell University, 1992. p.40-68.

VILLAÇA, M.; EZEQUIEL, J.M.B.; KRONKA, S.N. et al. Efeito de sementes de oleaginosas inteiras e óleo de soja sobre a digestibilidade in vitro e os padrões ruminais de bezerros Holandeses. Revista Brasileira de Zootecnia, v.28, p.654-659, 1999. 